\title{
WINDOW ON ANTARCTICA
}

ANTARCTIC OASIS: TERRESTRIAL ENVIRONMENTS AND HISTORY OF THE VESTFOLD HILLS. Pickard, J. (editor) 1986. Sidney, Academic Press Australia. $367 \mathrm{p}$, illustrated, hard cover. ISBN 0-12-554460-X. £26.50.

Antarctic oases are large patches of ice-free terrain that occur where ablation exceeds precipitation; they are the only large areas of the continent where radiation balance is positive, and 'windows' in the sense that bedrock Antarctica is visible through them. Unlike their counterparts in hot deserts they are not areas of high biological productivity; the aridity that ablates the snow cover makes them too dry to support vegetation, though they may have lakes (which are often saline) and seasonal streams. The Dry Valleys of McMurdo Sound, hitherto the best documented oases, are by far the largest and highest, with an area of more than $1000 \mathrm{~km}^{2}$ and rising above $2000 \mathrm{~m}$. The Vestfold Hills oasis, of area $411 \mathrm{~km}^{2}$ and maximum elevation $411 \mathrm{~m}$, is more representative of Antarctic oases as a whole. It lies inland from Davis, one of the permanent Australian stations of East Antarctica, and since 1957 Australian scientists have taken the trouble to investigate it thoroughly. This book is the very creditable result; a compilation of a dozen papers about the glaciological history, climate, and terrestrial and fresh water ecology of the Vestfold Hills oasis.

Pickard leads with an chapter that outlines the history of Antarctic oases and of this one in particular. It was discovered and landed on by the whaling captain Klarius Mikkelsen in February 1935 (his wife Karoline, who was with him, became the first woman to set foot on Antarctica). There follow three chapters on bedrock geology and crustal evolution, Cainozoic history, and physiography and geomorphology, which take full advantage of the large ice-free window. Chapter 5 is on climate, based largely on records from Davis with limited comparisons from a short-term inland station. The oases are in fact dry polar deserts, but what little life exists is of special interest; this is dealt with in chapters $6-11$, which cover algae, nitrogen fixation by cyanobacteria, bryophytes, lichens, spatial relations of vegetation, and invertebrates. The editor sums up in a short final chapter. These are research papers rather than reviews, together providing a useful regional survey of an ecologically remarkable area. (Bernard Stonehouse, Scott Polar Research Institute, University of Cambridge, Cambridge CB2 1ER.)

\section{BRIEF REVIEWS}

CLIMATE OF ANTARCTICA. Dolgin, I. M. 1986. Rotterdam, Balkema (Russian translations series 41). 213 p, illustrated, hard cover. ISBN 90-6191-463-9.

$£ 27.50$, US\$38.00.

A translation of Issledovaniya Klimata Antarktidy, papers presented at the All-Union Symposium on the Study of the Climate of Antarctica, held in Leningrad in 1976; the papers were published in Russian in 1980. Translated papers of Soviet conferences on issues of world interest are always welcome in the west, and Balkema does an excellent job of producing them in this series. It is unfortunate that so many of them appear so long-in this case a decade- after the delegates have gone home. 